\title{
Main Pathological Findings in Hydrocephalic Children Treated by Ventriculo-atrial Shunt
}

\author{
L. CROME and MAGDA ERDOHAZI \\ From Queen Mary's Hospital for Children, Carshalton, Surrey
}

Insertion of valved tubes connecting the cerebral ventricles and the heart is now the method of choice for dealing with progressive hydrocephalus in children. About 1,000 of these operations are performed yearly in the United Kingdom. The general results of this treatment are being studied in a number of centres and it is too early to express conclusions about it. It seems useful, however, to present here some of the pathological findings in a relatively large series of treated cases.

\section{Material}

A single or repeated insertion of a Spitz-Holter valve was carried out at Queen Mary's Hospital for Children, Carshalton, Surrey, on 220 hydrocephalic children. Of these, 35, 24 girls and 11 boys, died some time after the operation and came to necropsy. Spina bifida cystica with an Arnold-Chiari malformation of the brain was present in 30. The ages of the children ranged from 12 days to 4 years and the survival following the first insertion of the tube varied from 3 days to 4 years. An unknown number died outside the hospital and partial information about the pathological findings is available in only one of these. As controls, 24 untreated hydrocephalic children coming to necropsy, matched roughly for age, were also studied; 20 of these had spina bifida cystica.

\section{Results}

The main findings are listed in Table I. It contains only findings that might be relevant to the operation. Others, such as limb wasting, contractures, talipes, and kyphoscoliosis, are not considered.

\section{Discussion}

Pulmonary embolization. The incidence of this complication in 31 cases of this series has already been reported (Erdohazi, Eckstein, and Crome, 1966). That in the present series is given in Table II. Pulmonary embolization is unquestionably

Received October 11, 1965. related to the presence of the tube in the vein or heart, since all the untreated hydrocephalic controls were free from this complication. Similar results in smaller series have been reported previously by other workers (Anderson, 1959; Talner, Liu, Oberman, and Schmidt, 1961; Emery and Hilton, 1961 ; Noonan and Ehmke, 1963; Sperling, Patrick, Anderson, and Fyler, 1964; Emery, 1964).

The real incidence of pulmonary embolization must certainly be higher than is ascertainable in post-mortem material, when only a few samples of the lungs are examined. Many emboli in our cases were fresh. Some would possibly have been lysed before occluding the arterioles or immediately

TABLE I

Main Pathological Findings in 35 Cases of Hydrocephalus Treated by Ventriculo-atrial Shunt

\begin{tabular}{|c|c|c|}
\hline & $\begin{array}{l}\text { No. of } \\
\text { Cases }\end{array}$ & $\%$ \\
\hline Thromboembolic lesions of the lungs .. & $\begin{array}{c}18 \\
\text { (out of } \\
34 \text { cases) }\end{array}$ & 53 \\
\hline $\begin{array}{l}\text { Infection of CNS } \ldots \text {. } \ldots \\
\text { Gross abnormality of urinary system } \\
\text { Bronchopneumonia; pulmonary collapse } \ldots \\
\text { Thrombosis of right atrium or superior }\end{array}$ & $\begin{array}{l}17 \\
16 \\
13\end{array}$ & $\begin{array}{l}49 \\
46 \\
37\end{array}$ \\
\hline $\begin{array}{llll}\begin{array}{ll}\text { vena cava } \\
\text { Endocarditis }\end{array} & \ldots & \cdots & \cdots\end{array}$ & $\begin{array}{r}12 \\
4\end{array}$ & $\begin{array}{l}34 \\
11\end{array}$ \\
\hline $\begin{array}{llllll}\text { ter } & \ldots & \ldots & \ldots & \ldots & \ldots\end{array}$ & 3 & 9 \\
\hline
\end{tabular}

TABLE II

Incidence of Pulmonary Emboli in 34 Cases of Hydrocephalus Treated by Ventriculo-atrial Shunt

\begin{tabular}{|c|c|c|c|c|c|}
\hline \multirow[b]{2}{*}{ Valve cases } & \multirow[b]{2}{*}{. } & \multirow{2}{*}{$\begin{array}{c}\begin{array}{c}\text { No. of } \\
\text { Cases }\end{array} \\
34\end{array}$} & \multicolumn{3}{|c|}{ Number of Cases with Emboli } \\
\hline & & & \multicolumn{3}{|c|}{$18(53 \%)$} \\
\hline & & & Bland & Septic & Both \\
\hline & & & 12 & 5 & 1 \\
\hline Controls & .. & 24 & \multicolumn{3}{|c|}{ Nil } \\
\hline
\end{tabular}


following occlusion. A number of the small vessels showed organized thrombi with recanalization. It seems, however, that collateral circulation is usually sufficient to maintain viability of the lung after temporary occlusion of the smaller pulmonary vessels. Infection of the lung parenchyma does not occur following bland embolization in contrast to the inflammatory involvement of the lung tissue around vessels containing septic emboli.

Bland embolization does not depend on the presence of infection of the CNS, since the incidence of infection in the cases showing embolization was not greater than in those free from emboli.

Several authors have described clinically recognizable pulmonary hypertension in cases treated with ventriculo-atrial shunts (Talner et al., 1961; Noonan and Ehmke, 1963; Sperling et al., 1964). This aspect of the problem certainly merits further study.

\section{TABLE III}

Organisms Isolated in 17 Cases of Infection of the CNS *

\begin{tabular}{|c|c|c|c|}
\hline Organism & & No. of Cases & $\begin{array}{l}\% \text { of All Infections } \\
\text { of CNS }\end{array}$ \\
\hline $\begin{array}{l}\text { Pseudomonas pyocyanea } \\
\text { Proteus spp. } \\
\text { Staph. aureus } \\
\text { Staph. albus } \\
\text { Bact. aerogenes }\end{array}$ & $\begin{array}{l}\because \\
\cdots \\
\cdots \\
\cdots\end{array}$ & $\begin{array}{r}10 \\
3 \\
2 \\
2 \\
1 \\
1\end{array}$ & $\begin{array}{r}59 \\
18 \\
12 \\
12 \\
6 \\
6\end{array}$ \\
\hline
\end{tabular}

* Several of the above organisms were isolated jointly in a few cases.

Infection of CNS. The risk of infection does not appear to be significantly affected by the operation, the incidence being $49 \%$ in our treated cases and $58 \%$ in the untreated ones.

The organisms isolated from the infected cases are listed in Table III.

The most frequent organism in this series is Ps. pyocyanea and some aspects of this infection have already been discussed in a previous communication (Crome, 1964). The most constant change in such cases is choroiditis, and it seems likely that this may often precede meningeal involvement. Massive chronic pyocephalus was seen in two instances. One of the cases in this series had colonization of the Spitz-Holter valve by staphylococci, and was included in a series reported by Callaghan, Cohen, and Stewart (1961).

Renal anomalies. Thirty cases in this series had spina bifida cystica and since it is well known that this condition is frequently associated with pathological changes of the urinary tract it is not surprising that these were present in 16 cases of this series. The commonest was slight or moderate hydronephrosis and hydroureter (11 cases). Other changes included pyelonephritis and marked distension of the bladder.

Pulmonary collapse and bronchopneumonia. Terminal pulmonary complications are usual in all serious neurological diseases of infancy and do not appear to be significantly more frequent in this series.

Thrombosis of right atrium and vena cava. Thrombi at the atrial end of the distal catheter have been observed in most cases described by previous workers. They were less frequent in this series, occurring in only 12 cases. In 1 of these the thrombus was in the superior vena cava. In another, a solid cylindrical stalactite-like structure had formed, extending from the entrance of the superior vena cava to one of the papillary muscles. The end of the catheter was not in contact with this structure.

Endocarditis. Ulcerative bacterial endocarditis of the right atrium and/or tricuspid valve was present in 4 cases (Fig.). This complication had only been previously reported by Erdohazi et al. (1966).

Cardiac tamponade. Cardiac tamponade due to accumulation of CSF in the pericardium from a misplaced catheter was present in 3 cases. In one, the catheter was inadvertently inserted into the pericardium when a ventriculo-pleural shunt was attempted. In another, the end of the catheter had pierced the superior vena cava and was situated in the pericardial sac. In the third, the tip of the catheter was lodged in the ventricular myocardium close to the epicardium. The final pathological picture in all 3 cases was that of heart failure.

Miscellaneous. One of the cases dying outside this hospital had hydrocephalus not associated with spina bifida cystica and at necropsy showed a large tumour (ependymoma) of the 4th ventricle. This had occluded the cerebral aqueduct, but remained undiagnosed in life before and after the insertion of a Spitz-Holter valve. The tumour may have been congenital. The hydrocephalus was noticed at 10 months and the greatly raised intracranial pressure was relieved by the operation. Tumours causing obstructive hydrocephalus are exceedingly rare in infancy, but it is worth noting that a shunt operation may occasionally mask their presence as it did in this case. 


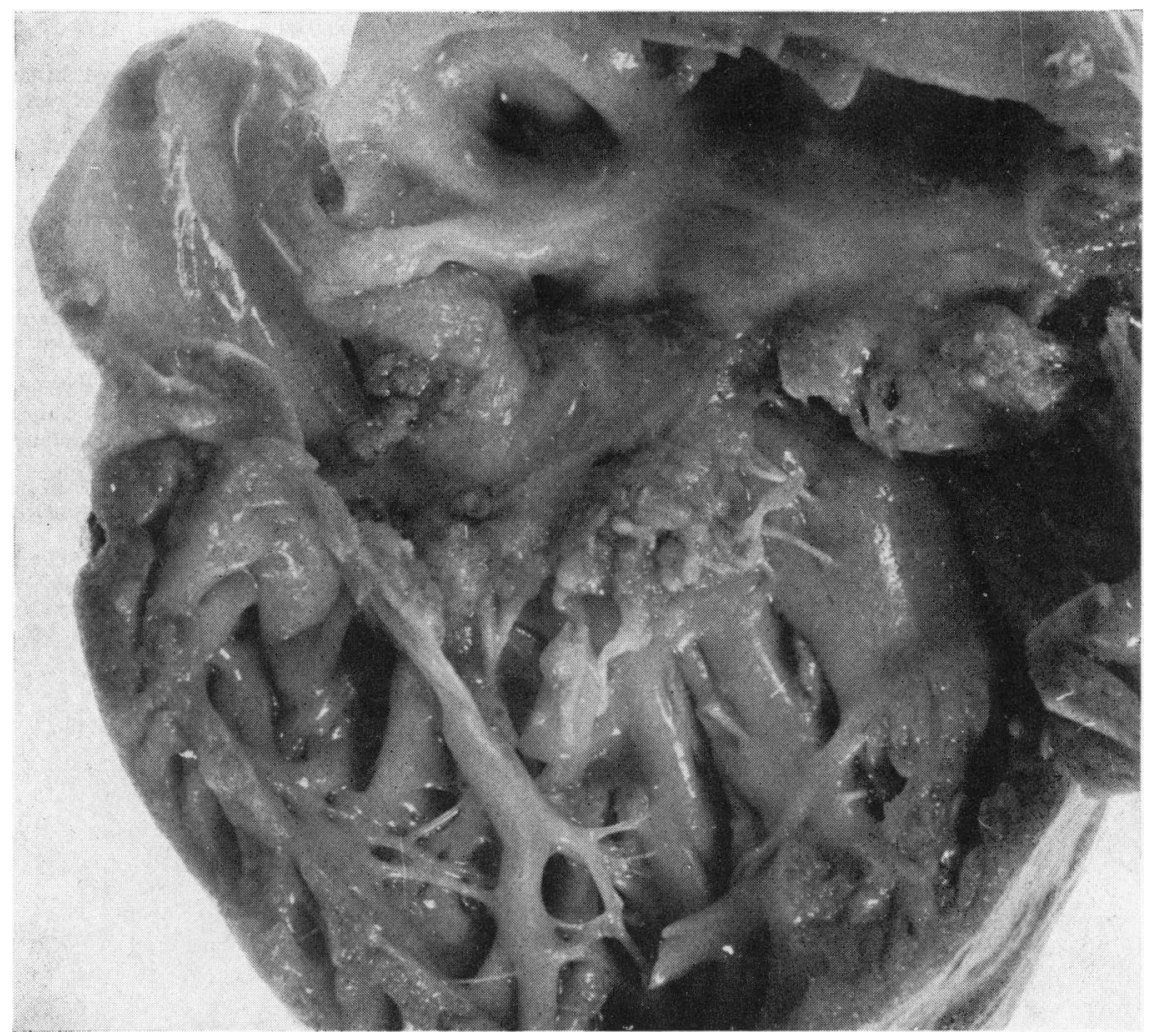

FIG.-Endocardial vegetations on the tricuspid valve and in the right atrium. $(\times 2 \cdot 83$.

Another unusual finding was cystic dilatation of the pineal body which was seen in one case. The cyst did not communicate with the ventricle and the pressure within it remained unrelieved by the ventriculo-atrial shunt.

Emery (1965) has recently published his observations on the changes in the brain in 44 hydrocephalic children with ventriculo-atrial shunts: 12 of these had lived more than 12 months after the operation. He found that their ventricles were not nearly as enlarged as in untreated cases. There was widening of the sulci and infolding of the cortex, thickening of the meninges, and increase of the subdural space with shrinking of the vessels crossing it. Subdural haemorrhage was not uncommon. Another important finding was upward displacement of the cerebellum and brain-stem caused, presumably, by shrinkage of the cerebral hemispheres resulting from continuous decompression. Emery examined the brains after fixation in situ. In the present series the brains were removed prior to fixation, and it is therefore not feasible to compare all the findings. We have not studied in detail the effect of decom- pression in this series. Nevertheless some of the changes described by Emery were undoubtedly also present in our cases. This applies particularly to the upward displacement of the cerebellum and brain-stem. On the other hand, we did not encounter any instances of subdural haemorrhage in the treated series, though one such case was seen among the untreated controls.

\section{General Conclusions}

The pathological findings discussed above indicate some of the problems which may be encountered following the insertion of the Spitz-Holter valve. It would be of interest to establish to what extent similar, but possibly less severe, complications account for the difficulties met with during life in the management of treated cases.

\section{Summary}

The pathological findings in 35 hydrocephalic children treated by the insertion of a Spitz-Holter valve included embolization of the lungs, infection 
of the CNS, thrombosis of the right atrium and superior vena cava, endocarditis, and cardiac tamponade due to misplaced catheter. Infection was as common in untreated cases, but the other changes were undoubtedly related to the surgical treatment.

We are indebted to Mr. H. H. Nixon, Mr. D. M. Forrest, and Mr. H. B. Eckstein, the surgeons at our hospital, who were in charge of the cases considered in this report, and to Mr. N. G. LePage for the photograph reproduced in this article.

\section{REFERENCES}

Anderson, F. M. (1959). Ventriculo-auriculostomy in treatment of hydrocephalus. $f$. Neurosurg., 16, 551.

Callaghan, R. P., Cohen, S. J., and Stewart, G. T. (1961). Septicaemia due to colonization of Spitz-Holter valves by staphylococci. Five cases treated with methicillin. Brit. med. F., 1, 860 .

Crome, L. (1964). Pyocyaneus-Meningitis bei Făllen von Spina bifida cystica. In Neurologie der Wirbelsäule und des Rücken- markes im Kindesalter, ed. D. Müller, No. 27, p. 223. Fischer, Jena.

Emery, J. L. (1964). Fibrin and thrombosis in the central nervous system in children with particular reference to congenital hydrocephalus. F. clin. Path., 17, 348.

(1965). Intracranial effects of long-standing decompression of the brain in children with hydrocephalus and meningomyelocele. Develop. Med. Child Neurol., 7, 302.

- , and Hilton, H. B. (1961). Lung and heart complications of the treatment of hydrocephalus by ventriculoauriculostomy. Surgery, 50, 309.

Erdohazi, M., Eckstein, H. B., and Crome, L. (1966). Pulmonary embolization as a complication of ventriculo-atrial shunts performed for hydrocephalus. Develop. Med. Child Neurol., 8, Suppl. 2.

Noonan, J. A., and Ehmke, D. A. (1963). Complications of ventriculovenous shunts for control of hydrocephalus. Report of three cases with thromboemboli to the lungs. New Engl. $\mathcal{F}$. Med., 269, 70.

Sperling, D. R., Patrick, J. R., Anderson, F. M., and Fyler, D. C. (1964). Cor pulmonale secondary to ventriculoauriculostomy. Amer. F. Dis. Child., 107, 308.

Talner, N. S., Liu, H., Oberman, H. A., and Schmidt, R. W. (1961). Thromboembolism complicating Holter valve shunt. A clinico-pathologic study of four patients treated with this procedure for hydrocephalus. ibid., 101, 602 . 